\title{
The Knowledge Landscape of School Disciplinary Committees on Disciplinary Policies in Mopani Education district, Limpopo Province, South Africa
}

\author{
Rifumuni Nancy Mathebula \\ University of Venda, School of Education, South Africa \\ https:/ / orcid.org/0000-0003-0780-563X \\ Tawanda Runhare \\ University of Venda, School of Education, South Africa \\ https://orcid.org/0000-0001-6142-7858
}

\begin{abstract}
Despite the clarity of the South African Schools Act (SASA) 84 of 1996 on the need to craft and implement a learners' Code of Conduct by school governing bodies (SGBs), there seems to be a gap between the espoused learner disciplinary policies and practice at schools. Using the case study research design, the knowledge scope on education policies by the school disciplinary committees (SDCs) was examined at two secondary schools in a predominantly rural South African district. The study employed a qualitative approach to gather data from purposefully selected informants using focus group and face-to-face interviews. The study sample was composed of 35 participants who were school disciplinary policy duty bearers, comprising 10 SGBs, 10 school management teams (SMTs) and 10 SDC members, as well as five class teachers. The main findings from the thematically analysed narrative data pointed to inadequate knowledge of policies by most SDC committee members. In addition, although the two schools had learners' codes of conduct that were aligned to SASA, the SDCs were loosely adhering to the provisions of the disciplinary policies in their operations. The gap between the espoused policy and policy in action was found to be due to the policy duty bearers' inadequate knowledge of the national policy that governs school discipline. This calls for the Department of Basic Education (DBE) to offer policy enhancement workshops for SDCs and to employ a policy monitoring instrument on the functioning of SCDs.
\end{abstract}

Keywords: duty bearers; knowledge landscape; learners' Code of Conduct; policy-in-action; school discipline 


\section{Introduction}

One significant attribute which determines the effectiveness of a school is good discipline (Burton \& Leoschut, 2013). Therefore, it is obligatory for schools to establish inclusive and respectful values that encourage and uphold the respect for human rights as this contributes to a conducive, safe and child-friendly teaching and learning environment (Republic of South Africa, 1996a; Republic of South Africa, 1996b; Du Plessis, 2010).

Whereas an atmosphere of safety is an essential for teaching, learning and educational growth (Department of Education, 2008; Mgijima, 2014), there is a challenge of a high prevalence of violence in South African schools (South African Council of Educators [SACE], 2011; Netshitangani, 2014; Mncube \& Steinmann, 2014; Basic Education Rights Handbook, 2017; UNESCO, 2017). Maphosa (2011) concurs that the occurrence of unruly behaviour is rapidly becoming a severe problem for teachers because a dangerous school atmosphere diminishes the quality of education in any school setting. On the same note, Joubert and Squelch (2005, p.23) attest that "to enable effective learning to take place, it is critical that a safe, secure and positive environment is created". The right to education is one of the fundamental human rights stated in virtually all international declarations and conventions such as the Universal Declaration of Human Rights (UDHR) of 1948, the Convention on the Rights of the Child (CRC) of 1989, and the Millennium Development Goals (MDGs) of 2000 (Runhare et al., 2014).

After 1994, the South African Schools Act 84 of 1996 (SASA) was passed into law, and among other provisions on school management, school governing bodies (SGBs) were established to deal with learner discipline (Republic of South Africa, 1996a). SASA, Section 10(1) indicates that inflicting corporal punishment on learners is prohibited and educators are required to find alternative means of maintaining school discipline (Republic of South Africa, 1996b; Basic Education Rights Handbook, 2017). It is in this regard that to maintain learner discipline, SASA Section 30(1) directs all SGBs to establish a legally structured and functional SDC as its key sub-committee (Republic of South Africa, 1996b; Joubert \& Prinsloo, 2008).

Studies have shown that functional school leadership is essential to establish and maintain a friendly teaching and learning environment (Joubert \& Bray, 2007; UNICEF, 2017). Rosen (1997) also acknowledges that maintaining a disciplined environment conducive for learning requires professional ethics which are provided by policies such as the school code of learner discipline, and the regulations that govern the operations of SGBs and SDCs. Therefore, schools need nationally aligned and detailed disciplinary codes to inform the management of learner discipline. It is also imperative that all SDC members have adequate knowledge of education policies on school discipline to design and implement their codes of learner discipline effectively at the school level. It was against this background that this paper reports on the knowledge base of SDC members at two rural South African schools on education policies that they should apply in maintaining learner discipline. 


\section{Literature Review}

Studies conducted confirmed that school violence is a global challenge (Burton \& Leoschut, 2013; Dunne et al., 2013; UNESCO, 2017; Ngidi, 2018). Similarly, in South Africa, the issue of indiscipline and unsafe school environments is of great concern (UNESCO, 2017; Basic Education Rights Handbook, 2017; Mgijima, 2014). Other studies conducted in South Africa found that school violence results in a loss of teaching and learning because the interruptions require to be attended to (Mkhize et al., 2011; Ncotsa \& Shumba, 2013; Netshitangani, 2014; Ngidi, 2018). On the same note, the Department of Education (2008, p.1) avows that "the school must be committed to provide an environment for the delivery of quality teaching and learning by promoting the rights and safety of all learners, educators and parents". Therefore SDCs, as policy duty bearers who are vested with powers to maintain school discipline, need to be knowledgeable about education policies as well as ensuring the proper implementation of and adherence to such policies by all school-based stakeholders, including learners.

Media reports regularly inform the community of the increase of misconduct occurrences in South African schools. Incidents of learners wounded and murdered within school boundaries are on the upsurge. To cite a few extreme incidents: on 07 June 2019, it was reported that a 16-year-old learner from a high school in Johannesburg was stabbed to death by a fellow learner. On 07 October of the same year, three learners from a secondary school in KwaZulu-Natal also stabbed a 16-year-old learner to death (Grobler, 2019; Sihlangu, 2019). Besides the school violence, there are other common forms of learner indiscipline. Earlier studies found that the commonest forms of disciplinary problems in schools are cheating in tests or examinations, insubordination, intimidation, watching pornographic material, inappropriate school uniform as well as classroom disruptions (Nene, 2013). However, learner misconduct is not unique to South Africa. A study conducted in Nigeria by Magwa and Ngara (2014) concurs that acts of indiscipline are also widespread in schools. The most predominant kinds of learner misconduct in Nigeria include unauthorised speaking, teasing other learners, absenteeism, verbal abuse of fellow learners and teachers, graffiti on school walls as well as drug abuse. In South Africa, Mncube (2014) observed that a lack of professionalism by teachers also results in violent discord in schools.

It is evident that the SDCs must be knowledgeable about disciplinary policies in order to manage school discipline and to handle serious cases which do not only violate the learners' Code of Conduct but breach the law as well. Based on the cited incidents, a well drafted learners' Code of Conduct cannot maintain discipline alone; SDCs must be knowledgeable to implement both national and school policies effectively. Similarly, Maphosa and Mammen (2011) supported by Smith et al. (2015) also indicated that managing learner discipline is a serious educational challenge and the SDCs should consider legal principles on discipling learners.

Such severe prevalence of school misconduct among learners implies that schools should have a strong knowledgeable governance structure to maintain 
and promote positive school discipline.

\subsection{Legislation of school disciplinary committees (SDCs) in South Africa}

As mentioned earlier, one major provision of the SASA 84 of 1996, Section 10(1) is the abolition of corporal punishment (Republic of South Africa, 1996b; Basic Education Rights Handbook, 2017). In 2000, the Department of Education published a document titled, Alternatives to Corporal Punishment: A Practical Guide for Educators (Department of Education, 2002; Joubert \& Prinsloo, 2008) which is meant to assist educators on non-violent means of maintaining learner discipline. These alternatives to corporal punishment include detention, time-out, behaviour management contracts, a points system and others. However, a study conducted by Nkabinde (2007) found that teachers failed to adopt available alternative methods to corporal punishment when disciplining learners because most of them still held that corporal punishment was the most suitable way of dealing with learners' ill-behaviour. A recent study by Mathebula et al. (2021) observed that corporal punishment or physical abuse of learners is still reported in South African schools.

Reflecting on the education system of South Africa before democracy in 1994, Morrell (2001) and Holdstock (1990) indicated that Bantu Education exposed black children to corporal punishment in South African schools. Morrell (1998) and Kubeka (2004) also concurred that corporal punishment was an integral part of school life for most teachers and learners in South African schools before the democratic dispensation in 1994. Similarly, in Botswana, Tafa (2002:17) revealed that " $[\mathrm{a}]$ horrendous form of discipline was also a common feature within the Botswana education system. Students complained that they were being beaten anywhere the teacher pleased for no reason, with sticks, 'sjamboks' [whips] and board dusters".

With the criminalisation of corporal punishment at schools, SDCs are vested with powers to maintain school discipline while considering the Constitution, SASA and Provincial Education Department's Regulations (Republic of South Africa, 1996b; Basic Education Rights Handbook, 2017). SASA endorses the key fundamentals of the Constitution of the Republic in the education system. According to SASA Section 30(1), SGB must establish a legally structured SDC as its key sub-committee (Republic of South Africa, 1996b; Joubert \& Prinsloo, 2008). The SDC comprises delegated members from the SGB, the SMT, the representative council of learners (RCL), parents or guardians of the child and class teachers. In this way, the state aims at adopting democratically nominated management for promoting acceptance, sensible discussion and shared decisionmaking. Harber and Mncube (2011) concur with SASA; they pointed out that a functioning school is one that works constitutionally to support democratic practices in the broader society.

SASA Section 8(1) also indorses that it is the legal obligation of the SGB to adopt a school Code of Conduct for learners after involvement of key school-based stakeholders, namely educators, support or non-teaching staff, parents and learners in a secondary school context. SASA Section 8(2) further upholds that 
the learners' code of ethics must aim to establish a disciplined and purposeful learning environment which protects the interests of all education stakeholders (Republic of South Africa, 1996b; Joubert \& Bray, 2007). Based on this, the South African Children's Act (2005, p.34) also endorses that "In all matters concerning the care, protection and well-being of a child, the standard that the child's best interest is of paramount importance, must be applied". Consequently, the schools need well constituted policy-literate disciplinary committees to maintain and promote good discipline which enhances a conducive teaching and learning environment.

As a way of promoting children's human and constitutional rights, the SDCs must be knowledgeable about education policies and the proper implementation of such policies in order to avoid the split between policy and practice. The SDCs must acquire knowledge through formal training at different levels. According to SASA, it is the duty of the principal and the school governance to offer training to all the sub-committees of the SGB (Republic of South Africa, 1996b). The availability of the Schools Act and well drafted learners` codes of conduct at schools do not guarantee the proper implementation of education policies to curb learner misconduct. Therefore, there is still a high prevalence of unruly behaviour in South African schools (UNESCO, 2017; Basic Education Rights Handbook, 2017; Ncotsa \& Shumba, 2013; Netshitangani, 2014; Ngidi, 2018). Regarding the improper implementation of education policies, Mugabe and Maposa (2013) observed that some teachers protected ill-disciplined learners during disciplinary hearings on the basis that strict monitoring of learners limited their freedom and creativity, which can negatively affect their academic performance.

Therefore, knowledge of the SDC on education policies is crucial; it affects the implementation of the national policy as well as the effectiveness of the SDCs as the policy duty bearers. On this note, this paper examines the knowledge landscape of the SDCs on disciplinary policies at the two selected rural secondary schools in the Mopani district.

\subsection{Operation of SDC for conducting school disciplinary hearings}

The major responsibility of school authorities and educators is the safety and well-being of all learners and staff members (Republic of South Africa, 1996b; Joubert \& Squelch, 2005; Department of Education, 2008; Du Plessis, 2010; Dune et al., 2013). As mentioned earlier, SASA directed the SGBs to establish a lawfully structured SDC as its key sub-committee. The main duty of the SDC is to conduct a fair disciplinary and impartial hearing while considering the due processes. These are procedural processes which refer to fair procedure and substantive processes relating to the appropriateness and fairness of disciplinary rules and any action taken against an alleged infringement by a learner (Republic of South Africa, 1996b; Joubert \& Prinsloo, 2008).

According to SASA, a disciplinary hearing must take place when a learner is alleged to have committed a very serious misconduct which may require suspension or expulsion. Examples of very serious misconduct are threats using 
dangerous weapons, forging documents, using or selling drugs and alcohol, assault, rape, robbery, sexual harassment, burglary, murder and others (Republic of South Africa, 1996b; SACE, 2011; Mncube \& Steinmann, 2014; Basic Education Rights Handbook, 2017). To promote fairness, the disciplinary hearing must be conducted in line with Constitution, SASA and provincial education department regulations.

Taking into consideration due process and the principle of fairness in all the actions taken against the alleged infringement by a learner, the SDCs are mandated to fulfil their delegated responsibilities to uphold democratic values when handling disciplinary cases. In order to improve efficiency and fairness, the SDCs must always ensure that ill-disciplined learners are treated equally and impartially and are protected against unfair treatment during disciplinary hearings. A study by Maphosa and Mammen (2011) revealed that handling issues of discipline is a challenge that requires proper and meaningful disciplinary measures that produce the desired results. In the same vein, Smith et al. (2015, p.2367) concur that "Disciplinary proceedings can have very serious results for learners, and it is therefore very important and that those conducting them should respect legal principles". Therefore, the SDC must be knowledgeable on education policies and uphold impartiality by considering the rules of natural justice which are given under Section 33 of the Constitution (Republic of South Africa, 1996a; Joubert \& Prinsloo, 2008).

Similarly, the education policies of South Africa and neighbouring Zimbabwe, both members of the Southern African Developing Community (SADC) on school discipline are comparable. Zimbabwe has, through the Ministry of Primary and Secondary Education (MOPSE), encouraged schools to use positive discipline practices on learners and to adopt democratic policies and measures to protect children from maltreatment, neglect or any form of abuse (Government of Zimbabwe, 2013; Ministry of Education, Sports, Arts \& Culture, 1999) as endorsed in the United Nations Convention on the Rights of the Child (UNCRC) Chapter 2 Article 2, 11 (UNCRC, 1989). Mugabe and Maposa (2013) indicated that various methods to manage learner misconduct include codes of conduct and rules, the prefect system, parental involvement, counselling and disciplinary committees. Punishment to ward off misconduct includes manual work, detention and exclusion and expulsion as the last resort used for extreme cases of indiscipline. In the United States of America (USA), zero tolerance policies on learner discipline were introduced in 1990 and 1994 for schools to deal with serious cases such as possession of firearms (Martinez, 2009; Brand, 2015). The zero tolerance policies recommend the suspension of a learner for one year without provision of home-based educational support. However, the policies were withdrawn in 2001 because school administrators abused them as they were used in handling less serious transgressions (Martinez, 2009).

\section{Research Problem}

The scourge of school-based violence is source of concern in schools in South Africa (Burton \& Leoschut, 2013; Leach et al., 2014; UNESCO, 2015; UNESCO, 2017; Ngidi, 2018). Mncube and Steinmann (2014) maintained that possession of 
dangerous weapons has become part of everyday life in South African schools. This is attributed to the magnitude of school violence which adversely affects the teaching and learning environment. In the same vein, Mkhize et al. (2011, p. 40) indicate that "School violence has an undesirable impact on the lives of young people, educators and parents, and it also negatively influences effective teaching and learning". Literature indicates that while SDCs, education policies and constitutional provisions on school discipline do exist in South African schools, the challenge of learner indiscipline still remains (Ncontsa \& Shumba, 2013; Burton \& Leoschut, 2013; UNESCO, 2015). All this implies that for effective operational teaching and learning, schools must have knowledgeable school management, disciplinary organs and procedures to monitor the proper implementation of school policies and measures that maintain school discipline. Based on a case study at two secondary schools in rural South Africa, this paper examines the results of an examination of SDC members' knowledge of the nature and implementation of espoused school disciplinary policies.

\section{Research Procedure}

In pursuit of the objective of this study, a case study research design was regarded as the most suitable (Yin, 2016) because this is a scientific study of a contemporary phenomenon in its natural situation or setting. The qualitative research approach that endeavours to comprehend phenomena in their natural context or real-world settings was employed for this study (Creswell, 2010). The study participants were drawn from two purposively selected secondary schools to represent rural schools with dysfunctional SDCs and more cases of learners' indiscipline. The schools were not chosen as quantitative representations but were selected because they provided rich and relevant data as they had high rates of learner indiscipline. However, findings from this study may not be generalised to a wider population of South African schools which may not have similar characteristics or situations as at the selected schools (Cohen et al., 2007). However, the results may be applicable to schools facing similar challenges as those found at the study sites of this research.

\subsection{Sampling approach and study sample}

Purposive sampling was used to select the 35 study participants according to their relevance to the specific research objective of this study (Cohen et al., 2007), namely that they were assumed to have knowledge of the policies and functioning of SDCs as they were office bearers at the time when the study was conducted. The 35 study participants included 10 SGBs, 10 SMTs, 10 SDC members and five class teachers who were active duty bearers in learner disciplinary cases that were brought to the SDC for adjudication.

The SGB is comprised of parents, teachers, support staff, the representative council of learners (RCL) in the case of secondary schools, and the principal as an ex-officio member. The SGBs were sampled because they are duty bearers and responsible for adopting the learners' Code of Conduct. The SGB also ensured that the discipline practices of the school take place within the framework of the Constitution of the Republic of South Africa and SASA 
(Republic of South Africa, 1996a; Republic of South Africa, 1996b; Joubert \& Prinsloo, 2008). Members of the SMT included the principal, deputy principal, heads of departments (HODs), senior teachers and co-opted members. The SMTs were sampled because they are policy implementers. The SMTs ensure that education policies, legislations and school policies are implemented, including the policy regarding discipline.

As alluded to earlier, the SDC is a sub-committee of the SGB which is mandated to conduct a disciplinary hearing if a learner had committed a very serious offence which violates school rules or breaches the law (Republic of South Africa, 1996b). SDC members were therefore sampled because they had conducted disciplinary hearings within the framework of the Constitution of the Republic of South Africa and SASA. Class teachers were sampled because they are in direct charge of teaching, interacting with learners and maintaining learner discipline in their classes and during extra-curricular activities. Class teachers teach and maintain discipline in accordance with the learner's Code of Conduct. The grade nine and ten class teachers were sampled because their learners were highly recorded in school discipline records.

\subsection{Data collection instruments}

Data were gathered using individual and focus group interviews (FGIs) to complement each other, and as a triangulation measure which strengthened study findings. The study opted to use focus group interviews as the main instrument for the research as most participants were involved, that is the SGBs, SDCs and SMTs. According to Robson et al. (2001), a focus group is an interview with a small group of people interviewed together rather than singly. Class teachers participated in individual interviews because of the sensitive and personal nature of their experiences on this topic. According to Creswell (2002), a face-to-face interview is a data collection process in which the researcher asks questions of and records answers from only one participant in a study at a time. Subsequent to the individual interviews, follow-ups were conducted on issues that emerged from a study of documents and the FGIs. The SDCs, SMTs and SGBs participated in focus group interviews because they may not be emotionally or personally affected by the issue being studied. FGIs deal with less sensitive issues and discuss the formulation of school policies. Moreover, focus group interviews assisted in triangulating data collection methods, such as face-to-face interviews and the documentary analysis used in this study.

Triangulation is defined as the use of two or more methods of data collection in the study of some aspect of human behaviour (Cohen et al., 2007). Semistructured interviews were employed in this study to validate data emerging from school records. Thereafter, focus group interviews were conducted followed by the individual interviews. For both individual and focus group interviews, interview schedules with open-ended questions to allow probing (Maree, 2011) were used. The interviews were audio-taped after permission to use an audio tape had been granted by the participants. Notes were made to support the 
recordings on issues that could not be captured orally. In addition, observations were noted during the interviews, especially about non-verbal cues. The composition of each interview group was homogenous with regard to authority differences or status differences. Care was taken to ensure that the various categories of individuals fell into separate focus groups, for instance, SGB members did not mix with the SMT members. All the interviews took place in the interview room (in this study it was a classroom). A copy of the interview schedule and the contact details of the researcher were provided to each interviewee for possible future enquiries.

Documents were also used to collect textual data. McMillan and Schumacher (2006) stated that an analysis of documents is a method of collecting data which is non-interactive and involves the investigation of cases by reviewing artefacts of collections from archives such as photos, diaries, minutes of meetings, video clips and other types of records in organisations. This study used circuit records on learner indiscipline, records of school discipline and attendance registers. Administrative documents such as the learners' Code of Conduct of the two secondary schools were also studied for a deeper understanding of what offences were committed by learners and how learner discipline is managed at the two participating schools.

\subsection{Data analysis}

The purpose of data analysis is to outline the data clearly; identify what is typical and atypical of the data; bring to light differences, relationships and other patterns existing in the data; and ultimately answer research questions (Creswell, 2002). Both thematic and content analyses were used in this study. Dawson (2009) explains this as an inductive method because themes emerge from the data and are not imposed upon it by the researcher. Following a thematic analysis process, data were collected and analysed concurrently. An interview summary form was produced for both individual and FGIs which was completed immediately after each interview session. Background analyses were also included, such as descriptions of the two participating secondary schools, their backgrounds, their socio-culture and school ethos, the interview rooms and the general environment of the schools. These formed part of the thematic analysis processes. The background analyses also helped to explain an emerging theme. Themes were generated from the views of the participants.

Maree (2011) explains content analysis as a logical approach to the analysis of qualitative data. Content analysis was used to identify, summarise, and make inferences on the content of views expressed by study participants. Content analysis was used because it enabled a large volume of quoted statements to be dealt with as well as identifying and monitoring inconsistencies or any change in the views of participants (Cohen et al., 2007). Data were analysed manually by looking for categories emerging from the responses. Both textual data from the school documents and the narrative data from the audio-recorded interviews were analysed. It was also noted how non-interactive information from school records related to or collaborated with interactive data which had been collected from the conducted interviews. 
Themes were generated from the views of the SGBs, SMTs, SDCs and class teachers on how education policies and disciplinary measures were implemented to manage learner discipline at their schools. The data were coded and content analysis was conducted by looking for specific words from which themes were identified. In this study, content analysis included the establishment of codes and breaking down data into themes and categories that could be used to constitute the findings of the study (Babbie \& Mouton, 2001; Hesse-Biber \& Leavy, 2006). Content analysis enabled huge volumes of verbatim statements to be managed, as well as locating and monitoring inconsistencies and changes in the perceptions of participants (Cohen et al., 2007).

\section{Quality Criteria Measures}

The researcher is a data-gathering instrument in qualitative research (Maree, 2011; Merriam, 2009). According to Lincoln and Guba (2005), trustworthiness relates to the way the researcher can convince the audience that the research is of high quality and worthy of recognition. The trustworthiness of this research phase was ensured by applying the following criteria: credibility, dependability, authenticity and confirming as briefly discussed below:

- Credibility of research instruments: According to McMillan and Schumacher (2001), credibility is the extent to which the results approximate reality and are judged to be accurate and reasonable. In this study, credibility was ensured by triangulating methods of data collection and sources of data and prolonging the engagement with participants in the study sites.

- Transferability of the study results: Transferability refers to the ability to apply the findings in other contexts or to other participants (Grix, 2004). Since the research was a case study involving only two schools, the study findings could not be generalised to all the schools in South Africa. However, the findings of this study can be transferred to schools and participants whose descriptions tally with those provided in the study. To improve transferability, the findings of the study, as recorded in the tape-recorder and written $\mathrm{up}$ in the field notes and a reflective journal, were defined in the form of themes and detailed explanations.

- Dependability of data collection instruments: Durrheim and Wassenaar (2002) state that dependability concerns the extent to which the findings of the study reflect the actual processes that occurred. Member checking was employed and the identified themes were discussed with the participants to ensure that they were accurate and dependable (Creswell, 2002). Comprehensive field notes were taken throughout the study. Those notes also included the general environment of the two schools, a study of documents and the interviewing process. In addition, the verbal and non-verbal cues of the participants were captured in detail during the interviews.

- Conformability of data sources: According to Merriam (2009), conformability means ensuring that the data findings represent the 
perspectives, meanings and views of the participants instead of the views and understanding of the researcher. The findings were scrutinised, and analysed, and self-critical accounts were considered. Data were recorded accordingly, interpreted and presented correctly and accurately.

\section{Results}

From collected data, the extent to which the knowledge of the SDCs on the knowledgeable implementation of education policies on school discipline at the two schools was aligned to SASA 84 of 1996 and democratic principles enshrined in the Constitution Bill of Rights (Republic of South Africa, 1996a) was examined. In line with this, the collected narrative data were summarised and discussed into three themes in this section, namely non-alignment of SDCs operations to national school policy, unprocedural disciplinary hearings and the employment of unlawful school office bearers handling disciplinary cases.

The objective of the study was to examine SDC members' knowledge of education policies on school discipline. As mentioned earlier, the school disciplinary hearing meetings are generally instituted when a learner commits a very serious misconduct which is in violation of school rules or a breach of the law. Ideally, when an undisciplined learner is brought before the SDC for a disciplinary process, delegated members from the SGB, SMT and RCL, parents or guardians of the child brought before the SDC and class teachers should be present to conduct an impartial disciplinary hearing. Impartiality depends on objective adherence to policy; this can happen if the representatives in the SDC are knowledgeable about the national policy. For the SDC to function effectively, the representation must be policy literate. The representatives must have knowledge of SASA, and the knowledge must be acquired through proper training at different levels (Republic of South Africa, 1996b; Basic Education Handbook, 2017; Joubert \& Prinsloo, 2008).

\subsection{Non-alignment of SDCs operations to national school policy}

Interviews with study participants revealed that SDCs had inadequate knowledge of what SASA 84 of 1996 entails. This implied that the implementation of school discipline policies at school level is more of a windowdressing activity by the principal-dominated SMT, with inadequate visibility of the actual SDC members. In this regard, a learner in the RCL who should be a sitting member of SDC proceedings confessed that "everything is done by the principal and teachers. We as learners have no say in how other learners are disciplined, we only hear about it". Also sidelined were parents who claimed that they only came to attend the SDC hearings when their children were in the wrong.

On another important disciplinary provision, narratives by most SDC members confirmed that the schools had learners' Codes of Conduct that were aligned with SASA though the policy duty bearers displayed unlawful policy practices, which implied inadequate knowledge of disciplinary policies that should guide them. However, as most South Africans would know, there was general acknowledgment by SDC members at both schools that every child has a right 
to education as enshrined in the country's Bill of Rights and SASA. This was made clear from the explanation by one SDC member that "We consider all learners' right to education. Even if a learner has committed [a] very serious offence, such learner is brought to [a] disciplinary hearing and not expelled from school". This was regarded as a positive indication and not surprising as most South Africans are conscious of their democratic rights.

On another positive note, almost all participants of this study were aware that no child could be punished using corporal means. This knowledge was illustrated by one SDC member from one of the schools who indicated that "Since SASA abolished corporal punishment, it is also outlawed in our learners' Code of Conduct. Teachers do not administer corporal punishment. They can use other forms of punishment that do not cause much pain on the child". From these narratives, it is evident that the several SDC members had relevant knowledge of what national constitutional and educational policies on education constituted as a human right and that inflicting pain on children is unlawful.

The distinction between SDC and SGB roles and responsibilities was not clear to many interviewed participants. According to policy, the SDC should be a subcommittee of the SGB with a special mandate to maintain and promote school discipline (Republic of South Africa, 1996b; Joubert \& Prinsloo, 2008). However, a worrying statement which demonstrated confusion on the workings of the SDCs was disclosed by one participant who indicated that "We had a learner who refused to cut his long hair (dreadlocks) and he was not co-operating. The matter was handled and resolved by the SDC". A matter which was supposed to be handled by the SDC according to policy was handled by the SGB.

A similar inappropriate working of the SDC was indicated by another SDC representative who concurred that "We work together with SGB; most of learner indiscipline cases are handled by them as the SGB works closely with the school principal. They help us to resolve such difficult cases". Another conflicting statement on how SDCs work was provided by an SGB who confirmed that "as [a] SGB, we monitor how the school is running, including disciplining learners".

The aforesaid statements revealed that the SGBs at the study sites operated as if they were the SDCs in maintaining learner discipline. The disclosure by study participants demonstrated a misunderstanding of the Schools Act regarding the roles and responsibilities of the SDC, whose role was confused with that of the SGB. Moreover, school principals did not help to educate the community representatives. Such misapprehension from members who are supposed to be custodians of school policy was evidence that both the SGBs and SDCs at both schools had insufficient knowledge of school discipline; thus disciplinary procedures were not adhered to. Despite the clause in the Schools Act which endorses that the learners' Code of Conduct should clarify the roles and responsibilities of various school-based stakeholders (Republic of South Africa, 1996b), from the gathered narratives, it appeared that there was inadequate demarcation between SGB and SDC on the responsibility of maintaining school discipline, which was indicative of knowledge gaps among school policy duty bearers. 


\subsection{Unprocedural process of disciplinary hearings}

To assess the upholding of democratic principles by the SDCs, the SDCs' level of knowledge on conducting disciplinary cases should be aligned to the provision of SASA which directs that if there is serious case committed by a learner, the principal should report the case to the SGB. The SGB should then constitute an SDC as a sub-committee and hand over such a case to the SDC to conduct a fair disciplinary hearing process (Republic of South Africa, 1996b). However, although interviews with members who had participated in SDC disciplinary proceedings established that they claimed to have knowledge of education policies on school discipline, there was inadequate following of laid-down procedures for conducting disciplinary cases. This was a revelation of inadequate knowledge of what was claimed by the interviewees. Despite the fact that the Schools Act mandates the SGB to form a democratically constituted SDC, the principals and their deputies were regarded or acted as SDCs at the two schools. The fact on the ground was that SDCs were not functional because the principals handled disciplinary cases without involving the SDC members or other key school-based stakeholders such as class teachers and parents. The nonprocedural practice was disclosed by an SDC member who revealed that "Some cases are not worth the involvement of parents; the principal and the SMT usually handle such cases within the school without involving parents".

A comparable statement which also demonstrated procedural practice was disclosed by another SDC member who outlined that "In some cases, parents are called [on the] same day to meet with the principal and the SDC for disciplinary hearing meeting".

The narratives revealed that the SGBs involved parents informally in cases where their children were to be disciplined. Moreover, this process is managed by the school principal and the SGB without a formally instituted SDC as provided by the policy (Republic of South Africa, 1996b; Joubert \& Prinsloo, 2008). The Schools Act provides that for a fair hearing to take place, a parent or guardian of a child or a delegated person must attend a disciplinary hearing unless there is a valid reason given by the school governors for the continuance of the disciplinary proceedings in the absence of a parent (Republic of South Africa, 1996b; Basic Education Rights Handbook, 2017; Joubert \& Squelch, 2005; Department of Education, 2008). According to the Schools Act, the SDC must be well constituted and form a quorum and the disciplinary hearing meeting must be formal, civil as well as professional (Republic of South Africa, 1996b; Joubert \& Prinsloo, 2008). In contrast to this official principle, arm-twisting of the law by the school principal and the SGB were observed in violation of learners and parents' consent, formal procedures and composition of the SDC for hearing disciplinary cases.

\subsection{Unlawful school office bearers handling disciplinary cases}

Owing to their professional and governance responsibilities, the SDC policy duty bearers are expected to be more knowledgeable about SASA. By virtue of their professional and governance status, both SMTs and SGBs are policy and office bearers who are expected to advocate the implementation of education policies within schools. However, the study found that both the SMTs and SGBs 
had insufficient knowledge of education policies on school discipline which resulted in unlawful functioning and interference in learner discipline by school management.

One statement which demonstrated improper reporting procedure was revealed by a head of department in the SMT at one school who specified that "We report serious cases to the deputy principal or the principal. Then the principal reports to the SGB which conducts the full disciplinary hearing". This indicated that the school principal and the SGB did not constitute a formal SDC to conduct a disciplinary hearing. This was also reported by Mncube (2009), namely that school principals take precedence over all matters that should be handled by other managerial structures of schools in South Africa. Such domination could translate to inadequate dissemination of information on policy and procedures on learner discipline. This may be prevalent not only at the two schools where this study was conducted but at others as well.

The central role of school principals in disciplining learners was confirmed by class teachers from both schools who revealed that "I just go to the office and explain what happened. The principal or deputy principal normally send[s] illdiscipline]d] learners to call their parents. If the parent is available, they solve the case [the] same day or suspend the learner [at the] same time".

A similar statement indicating the inappropriate reporting and handling of disciplinary processes was shared by another class teacher from the other school who concurred that "We remove the ill-disciplined learner from the class. The principal deals with the case; if the learner is not co-operating, they issue [a] suspension letter [at the] same time".

However, a different practice on reporting and administering disciplinary cases was shared by a SGB representative member from the other school, which indicated involvement of the SDC. It was reported that "When a learner commits a serious offence, the teacher reports to us during the SGB meetings and we question the learner to prove if the allegations are true. Then we call the SDC to conduct the disciplinary hearing on the learner". Contrary to what happens at the other school, this indicated that at one of the schools, there was a democratic application of school disciplinary policy which revealed some level of dissemination of information on policy.

From the narratives, it appeared that class teachers only reported severe cases which they cannot handle to the school principals, who then acted at their own discretion rather than use the formal disciplinary procedures which are outlined in the school learners' disciplinary code. It therefore emerged that principals and deputies unilaterally acted as the SDCs and the school learners' disciplinary codes were espoused policies and not enacted policies. This noted domination of principals and their deputies in disciplinary procedures resulted in SDCs' being dysfunctional and ineffective in managing learner discipline.

The narratives by respondents revealed that the SGBs were more prominent than the SDCs in maintaining learner discipline. It was noted $t h$ at the 
reporting procedures were not procedural and therefore unfair to learners as policy rights beneficiaries. Owing to the benefit of their academic status, it was concluded that the teachers and school principals, as SMTs, were sufficiently knowledgeable of the Schools Act; however, it was disturbing that there seemed to be inadequate distribution of responsibilities with other policy duty bearers such as the representative council of learners (RCL) and non-academic members in SGB and SDC.

This resulted in prejudicing learners and contravening the Bill of Rights which protects their right to just and democratic hearings when they are found to have committed an act of misconduct (Republic of South Africa, 1996a; Du Plessis, 2010).

\section{Discussion of Results}

Data gathered from narratives revealed functional inefficiencies and discrepancies regarding the working of the SDC due to policy misapprehension at the two participating schools. The study revealed that SDCs were minimally knowledgeable of what SASA requires in terms of having a learner disciplinary code at their schools. Moreover, there was a clear gap between this basic knowledge and the implementation of the school codes in practice. In other words, there was no policy-in-action at the schools where the study was conducted. The national policy exists on paper; however, it was not implemented satisfactorily in practice owing to a lack of or inadequate training of SDCs at different levels. On the same note, Smith et al. (2015) pointed out that the SDC members generally have a sound knowledge of disciplinary processes which was gained through years of experience rather than through formal proper training.

The study revealed that the non-teaching members in the SGBs had inadequate knowledge of how disciplinary cases should be conducted; therefore there were no proper procedures on conducting disciplinary cases. Although SASA Section 8(5) indorses due processes which need to be followed when conducting disciplinary hearing of a learner (Republic of South Africa, 1996b), the SDCs were not clearly defined or constituted by the SGBs at the two schools. Instead, the SMT, especially the principals and their deputies, took on the roles of SDCs. This is contrary to national policy and has resulted in the disciplinary committees being non-existent, ineffective and dysfunctional. Similarly, Tallam et al. (2015) also found that most SDCs are ineffective in managing learner discipline as provided by stated national policies.

While the role of the SDC is to ensure that the disciplinary hearing is objective and unprejudiced, unlawful acts by the SDCs were noted which resulted in unfair treatment of ill-disciplined learners. Even though the most significant principle of the disciplinary hearing process is fairness, in practice, it appears that the national policy is not generally applied correctly which has resulted in unlawful and unconstitutional practices by the SDCs. The dominance of the principals and their deputies in handling disciplinary cases while excluding the SDC members was found to be the major factor contributing to unlawful 
practices by the SDCs. Section 12(1) endorses that the disciplining of learners must be fair and justifiable (Republic of South Africa, 1996a). Meanwhile South Africa's endorsement of international resolutions such as the Universal Declaration of Human Rights (UDHR) (1948), the United Nations (UN) Convention on the Rights of the Child (CRC) (1989) and the African Charter on the Rights and Welfare of the Child (ACRWC) (1990) have all emphasised the state's commitment to safe-guarding children from all violations of their rights (Basic Education Rights Handbook, 2017).

This study revealed that while stakeholders had general knowledge on child rights, there was no evidence that these principles were practised at school level or applied in learner disciplinary procedures. It emerged from the study that due processes were not adhered to when handling disciplinary cases at the two participating schools. Data revealed that there were no proper procedures of reporting and conducting disciplinary cases using properly constituted SDCs as sub-committees of SGBs. This unlawful and unconstitutional practice of not employing SDCs is against the Bill of Rights as endorsed in Section 33 subsection (1) which ratifies that an individual has a constitutional right to a legal, rational and impartial hearing (Republic of South Africa, 1996a). Meanwhile the national development plan espouses that education districts should provide support to improve appropriate policy and practices within schools (Republic of South Africa, 2011).

\section{Conclusion}

This paper concludes that there were discrepancies between policy implementation and common practice regarding how schools manage learner discipline. Considering the objective to examine the knowledge of SDCs on education policies on school discipline, the following common findings were identified from the two study sites: Both schools had sound learners' Codes of Conduct (LCCs) aligned with SASA; however, in practice, the SGBs did not have formal SDCs and did not adhere to the national policy on learner discipline owing to inadequate knowledge of the formal application of their LCCs. It was therefore concluded that the actual SDCs were dysfunctional owing to the domination of school managers when conducting disciplinary hearings. From narratives obtained from school disciplinary committees (SDCs), school management teams (SMT), school governing bodies (SGBs), representative councils of learners (RCLs) and class teachers, it is evident that disciplinary hearings are mostly handled in an informal, unfair and unconstitutional way which infringes on children's human and constitutional rights. In view of the improper interpretation and implementation of national policy by the SDCs due to inadequate knowledge, it is recommended that the Department of Basic Education (DBE) should offer training and monitor the structure and functioning of the SGBs, SDCs and LCCs. This should ensure appropriate alignment and implementation of SASA on how learner discipline should be administered by the SDCs.

\section{Acknowledgement}

This work is based on research supported by the National Research Foundation 
of South Africa (Grant Number: 120744). However, opinions, findings and conclusions or recommendations expressed are those of the authors. The NRF accepts no liability whatsoever in this regard.

\section{References}

Babbie, E., \& Mouton, J. (2001). The practice of social research. Oxford University Press.

Brand, A. (2015). Biting the bullet: Why the Gun-Free Schools Act must be repealed to protect student speech. Marshall Law Review, 49(2), 593-624.

Basic Education Rights Handbook (2017). Education rights in South Africa. Section 27.

Burton, J., \& Leoschut, L. (2013). School violence in South Africa: Results of the 2012 National School Violence Study, Monograph Series No. 12. Centre for Justice and Crime Prevention.

Charles, C. M. (2008). Building classroom discipline $\left(9^{\text {th }}\right.$ ed.). Allyn and Bacon.

Cohen, L., Manion, L., \& Morrison, K. (2007). Research methods in education (6 ${ }^{\text {th }}$ ed.). Routledge Falmer.

Creswell, J. W. (2002). Educational research: Planning, conducting and evaluating quantitative and qualitative research. Pearson Education.

Creswell, J. W. (2010). First steps in research (5 ${ }^{\text {th }}$ ed.). Van Schaik Publishers.

Dawson, C. (2009). Introduction to research methods. A practical guide for anyone undertaking a research project ( $4^{\text {th }}$ ed.). How to Books.

Du Plessis, P. (2010). School safety - who is liable anyway? Journal of Education Studies, 9(2), 108-124.

Dunne, M., Sabates, R., Bosumtwi-Sam C., \& Owusu, A. (2013). Peer relations, violence and school attendance: Analyses of bullying in senior high schools in Ghana. Journal of Development Studies, 49(2), 285-300. https://doi.org/10.1080/00220388.2012.671472

Durrheim, K., \& Wassenaar, D. (2002). Putting design into practice: Writing and evaluating research proposals. Sage.

Government of Zimbabwe. (2013). Constitution of Zimbabwe. Harare: Government Printers.

Grix, J. (2004). The foundations of research. Palgrave Macmillan Publishers.

Grobler, R. (2019). Violence in SA's schools is worse than you think, and spanking is part of the problem. News24. https://www.news24.com/news24/SouthAfrica/News/violence-in-sasschools-is-worse-than-you-think-and-spanking-is-part-of-the-problem-20190607

Harber, C., \& Mncube, V, S. (2011). Is schooling good for the development of society? The case of South Africa. South African Journal of Education, 31, 233-245. https:// doi.org/10.15700/saje.v31n2a483

Hesse-Biber, S.N., \& Leavy, P. (2006). The practice of qualitative Research. Sage.

Holdstock, T. L. (1990). Violence in schools: Discipline. Oxford University Press.

Joubert, R., \& Bray, E. (2007). Public school governance in South Africa. CELP.

Joubert, R., \& Prinsloo, S. (2008). The law and a practical guide for education. Van Schaik Publishers.

Joubert, R., \& Squelch, J. (2005). Learner discipline in schools (2 ${ }^{\text {nd }}$ ed.).CELP.

Kubeka, W. M. (2004). Disciplinary measures at the Moduopo Primary School in Tembisa, Gauteng Province, South Africa after 1994 (Master of Technology dissertation). Tshwane University of Technology, Pretoria.

Leach, F., Dunne, M., \& Salvi F. (2014). School-related gender-based violence: A global review 
of current issues and approaches in policy, programming and implementation responses to school-related gender-based violence (SRGBV) for the education sector. UNESCO.

Lincoln, Y. S., \& Guba, E. G. (2005). Paradigms and perspectives in contention. Sage.

Magwa, S., \& Ngara, R. (2014). Learner indiscipline in schools. Review of Arts and Humanities, 3(2), 79-88.

Maphosa, C. (2011). Learners' perceptions of possible approaches to curb learner discipline in South African schools. Anthropologist, 13(4), 241-248. https://doi.org/10.1080/09720073.2011.11891204

Maphosa, C., \& Mammen, K. J. (2011). Learners' views on the effects of disciplinary measures in South African schools. Journal of Social Sciences, 28(3), 153-160. https://doi.org/10.1080/09718923.2011.11892940

Maree, K. (2011). First steps in research. Van Schaik Publishers.

Martinez, S. (2009). A system gone beserk: How are zero-tolerance policies really affecting schools? Preventing School Failure: Alternative Education for Children and Youth, 53(3), 153-158. https://doi.org/10.3200/PSFL.53.3.153-158

Mathebula, R. N., Runhare, T., \& Marishane, N. (2021). A critique of the democratic functionality of the school disciplinary committee structures within a South African rural setting. Journal of Educational and Social Research, 11(1), 170-187. https://doi.org/10.36941/jesr-2021-0017

McMillan, J.H., \& Schumacher, S. (2001). Research in education: A conceptual introduction. Longman.

McMillan, J. H., \& Schumacher, S. (2006). Research in education: Evidence-based inquiry. Allyn and Bacon.

Merriam, S. (2009). Case study research in education: A qualitative approach. Jossey-Bass.

Mgijima, M.N. (2014). Violence in South African schools: Perceptions of communities about a persistent problem. Mediterranean Journal of Social Sciences, 5(14), 198-206. https://doi.org/10.5901/mjss. 2014. v5n14p198

Ministry of Education Sport and Culture (MoESC), Zimbabwe. (1999). Policy Circular Minute: Discipline in schools: Suspensions, exclusion, expulsion and corporal punishment. MoESC.

Mkhize, S., Gopal, N., \& Collins, S. J. (2012). The impact of community violence on learners: A study of a school in the Swayimana rural area. Southern African Journal of Criminology, 1, 38-45. https://hdl.handle.net/10520/EJC138456

Mncube, V. S. (2009). Perceptions of the principal's role in democratic school governance in South Africa. Journal of Educational Administration and History, 41(1), 29-43. https://doi.org/10.1080/00220620802604594

Mncube, V.S. (2014). Preventing violence in South African schools: Control and punish or more effective school management. Mediterranean Journal of Social Sciences, 5(3), 416-422. https://doi.org/10.5901/mjss.2014.v5n3p416

Mncube, V., \& Steinmann, C. (2014). Gang-related Violence in South African Schools. $\begin{array}{llll}\text { Journal of } & \text { Social } & \text { Sciences, }\end{array}$ 211. https://doi.org/10.1080/09718923.2014.11893283

Mncube, V., \& Netshitangani, T. (2014). Can violence reduce violence in schools? The case of corporal punishment. Journal of Sociology and Social Anthropology, 5(1), 1-9. https://doi.org/10.1080/09766634.2014.11885603

Morrell, R. (1998). Of boys and men: Masculinity and gender in Southern African studies. Journal of Southern African Studies, 24, 605-630.

Morrell, R. (2001). Corporal punishment and masculinity in South African schools. Men and Masculinities, 4, 140-157. https://doi.org/10.1177/1097184X01004002003 
Mugabe, J. M., \& Maphosa, D. A. (2013). Methods of curbing learner misconduct in Zimbabwean secondary schools. International Journal on New Trends in Education and Their Implications, 4(4), 111-122.

Ncontsa, V, N., \& Shumba, A. (2013). The nature causes and effects of school violence in South African high schools. South African Journal of Education, 33(3), 1-15.

Nene, Z.F. (2013). Challenges of managing learner discipline: The case of two schools in Pinetown District [Master of Education dissertation, Educational Management Faculty of Education, School of Education, University of KwaZulu-Natal, South Africa].

Netshitangani, T. (2014). Causes of school-based violence in South African public schools: Application of normalisation theory to understand the phenomenon through educators' perspectives. Mediterranean Journal of Social Sciences, 5(20), 1394-1402. https://doi.org/10.5901/mjss.2014.v5n20p1394

Ngidi, L. Z. (2018). Reducing school violence: A peace education project amongst stakeholders in Umlazi [Doctor of Philosophy thesis, Public Administration Faculty of Management Sciences, Durban University of Technology, South Africa].

Nkabinde, S. (2007). Management of discipline in primary schools in Bhekuzulu Circuit. [Master of Education dissertation, Department of Educational Studies, Faculty of Humanities, Tshwane University of Technology, South Africa].

Republic of South Africa. (1996a). The Constitution of South Africa Act No. 108 of 1996. Government Printer.

Republic of South Africa. (1996b). South African Schools Act No. 84 of 1996. Government Printer.

Republic of South Africa. (2011). National Development Plan. Vision for 2030. National Planning Commission. Government Printer.

Republic of South Africa. South Africa Children`s Act. (2005). Act No. 38 of 2005. Government Printer.

Republic of South Africa. Department of Education. (2008). Example of a Code of Conduct for a school. Government Printer.

Robson, L. S., Shannon, H. S., Goldenhar, L. M., \& Hale, A. R. (2001). Evaluating the effectiveness of strategies for preventing work injuries: How to show whether a safety intervention really works. National Institute for Occupational Safety and Health.

Rosen, L. (1997). School discipline: Best practices for administrators. Corwin Press.

Runhare, T., Vandeyar, S., Mulaudzi, O., \& Dzimiri, P. (2014). Democratisation of formal schooling for pregnant teenagers in South Africa and Zimbabwe: Smoke and mirrors in policy. Gender \& Behaviour, 12(2), 6382-6395.

Sihlangu, J. (2019). Hillcrest school stabbing: Gang members terrorise Mossel Bay learners. The South African. https://www.thesouthafrican.com/news/mosselbay-school-stabbing-gang-members-terrorise-learners

Smith, A., Beckmann, J., \& Mampane, S. (2015). Experiences and challenges of evidence leaders ("prosecutors") in learner disciplinary hearings in public schools. Potchefstroomse Elektroniese Regsblad, 18(6), 2365-2403. http://dx.doi.org/10.4314/pelj.v18i6.10

South African Council of Educators (SACE). (2011). An overview of school-based violence in South Africa. South African Council of Educators.

Tafa, E. M. (2002). Corporal punishment: The brutal face of Botswana's authoritarian schools. Educational Review, 54, 17-26.

Tallam, E. K., Tikoko, B. J., Jackline, S., \& Daniel, K. C. (2015). Contribution of school disciplinary committee to the management of students' discipline in public secondary schools in Rongai district, Nakuru County, Kenya. Educational 
Research, 6(5), 109-112. http:/dx.doi.org/10.14303/er.2015.098

United Nations Convention on the Rights of the Child (UNCRC). (1989). United Nations Convention on the Rights of the Child. UNCRC.

United Nations Educational, Scientific and Cultural Organization (UNESCO). (2015). Positive discipline in the inclusive, learning friendly classroom. A guide for teachers and teacher educators. UNESCO.

United Nations Educational, Scientific and Cultural Organization (UNESCO). (2017). School violence and bullying: Global Status Report. UNESCO.

Yin, R. K. (2016). Case study research. Design and methods (5 $5^{\text {th }}$ ed.). Sage. 